\title{
PENGELOLAAN DANA OTONOMI KHUSUS BIDANG PENDIDIKAN DI KABUPATEN NABIRE
}

\author{
Penulis: \\ Makaria Tatogo ${ }^{1}$ \\ mkduncenjurnal@gmail.com \\ Theo Allo Layuk ${ }^{2}$ \\ theoallolayuk1965@gmail.com \\ B. Elita Bharanti ${ }^{3}$ \\ ebonifasia@yahoo.com
}

\begin{abstract}
The objective of the research is to explore in depth the management process, and utilisation of Special Autonomy Fund provided for Education Sector for Native People in Nabire Regency. Methods of data collection using Observation, Interview, and Library Studies. We analyse the data utilising the qualitative approach. The results of this study reason some problems that are: unproperly managed, low synchronisation in planning, lack of coordination in implementation, and delay in reporting. Another problem is the socialisation of the funding regulation.
\end{abstract}

Keywords: Special Autonomy, Management of OTSUS, Education, Triangulation

\section{PENDAHULUAN}

Kabupaten Nabire dengan luas wilayah sekitar $12.075 \mathrm{~km} 2$ atau 16,70\% dari luas Provinsi Papua yang terdiri dari 15 Distrik, 89 Kampung dan 9 Kelurahan dengan jumlah penduduk sebanyak 140.178 jiwa. Persoalan Pembangunan di Provinsi Papua selalu ditandai dengan tantangan kondisi geografis yang sangat sulit untuk dijangkau hingga pada tingkat kampung, sehingga Pemerintah Pusat menawarkan Otonomi Khusus untuk mengejar ketertinggalan, pemerataan pembangunan dan menjawab aspirasi masyarakat Papua yang menuntut merdeka.

Dengan Undang-Undang Nomor 21 Tahun 2001 tentang Otonomi Khusus bagi Provinsi Papua, Negara memberikan pengakuan ke-khusus-an kepada Papua untuk memiliki kewenangan khusus guna mengatur pemerintahan dan pembangunan menurut Kepentingan masyarakat melalui

\footnotetext{
${ }^{1}$ Alumni Mahasiswa Magister Keuangan Daerah Universitas Cenderawasih

2 Staf Dosen Jurusan Akuntansi Fakultas Ekonomi \& Bisnis Universitas Cenderawasih

${ }^{3}$ Staf Dosen Jurusan Manajemen Fakultas Ekonomi \& Bisnis Universitas Cenderawasih
} 
prakarsa sendiri berdasarkan aspirasi dan hak-hak dasar Masyarakat Papua. Kebijakan khusus diakui sebagai bagian dari otonomi asimetris yang diberikan kepada Tanah Papua.

Pengimplementasian Udang-Undang Nomor 21 tahun 2001 ditetapkan adanya dana Otonomi Khusus. Dana Otsus adalah Penerimaan khusus dalam rangka pelaksanaan Otonomi Khusus yang besarnya setara dengan 2 persen dari plafon dana alokasi umum nasional, yang pengunaanya terutama ditujukan untuk pembiayaan Pendidikan dan Kesehatan dan Pelayanan Ekonomi Kerakyatan yang berlaku selama 25 tahun, mulai tahun 2001.

Dalam perencanaan dan pengelolaan Otonomi Khusus tersebut masih terhambat oleh lambatnya penyusunan peraturan pelaksanaan yang diperlukan seperti Peraturan Daerah Provinsi dan Peraturan Daerah Khusus, Akan tetapi dalam pelimpahan kewenangan peruntukan dana Otonomi Khusus Sejak Tahun 2002 hingga tahun 2013 didistribusikan 40 Persen untuk Provinsi Papua dan 60 Persen untuk Kabupaten/Kota.

Hal ini dilihat tidak efektif maka terjadi perubahan kebijkan pembagian belanja Dana Otsus ke Kabupaten/Kota oleh Gubernur Papua Bapak Lukas Enembe pada Tahun 2013 yang selanjutnya kebijakan tersebut diatur dalam Peraturan Daerah Khusus Nomor 13 Tahun 2016 tentang Pembagian Penerimaan dan Pengelolaan Keuangan Dana Otonomi Khusus.

Peruntukan Dana Otonomi Khusus sesuai Perdasus Pasal 8 ayat 1 dibagi dengan proporsi untuk Provinsi Papua 20 persen dan untuk Kabupate/Kota se Provinsi Papua 80 persen, pengalokasian dana Otsus tersebut diperuntukan : 1) Untuk Urusan Pendidikan mendapat prioritas utama penyaluran dana Otonomi Khusus Minimal sebesar 30 persen, untuk membiayai PAUD 5 persen, Pendidikan Dasar 9 tahun (15), Pendidikan menengah 6 persen dan Pendidikan tinggi 4 persen. 2) Untuk urusan Kesehatan mendapat dana minimal sebesar 15\% untuk membiayai Pelayanan kesehatan dasar, Pelayanan kesehatan rujukan, Pencegahan dan pemberantasan penyakit, perbaikan gizi masyarakat, pembinaan 
kesehatan lingkungan dan pelayanan kesehatan dalam situasi bencana. 3) Untuk Urusan Ekonomi Kerakyatan mendapat dana minimal sebesar 20 persen utuk membiayai perkreditan usaha ekonomi rakyat, dana bergulir, subsidi harga kebutuhan 9 bahan pokok dan pengembangan komoditi unggulan. 4) Untuk pembangunan infrastruktur dasar kampung minimal 20 persen yang dialokasikan untuk pembangunan sarana dan prasarana perumahan rakyat, penerangan, air bersih, dan telekomunikasi. 5) Untul Bantuan afirmasi 5 persen kepada lembaga keagamaan, lembaga masyarakat adat asli, dan kelompok perempuan. 6) Untuk perencanaan dan pengawasan Pemerintah Daerah, monitoring dan evaluasi, pengawasan dewan, pelaporan program kegiatan 5 persen.

Sebagai program prioritas, permasalahan pendidikan di Papua lebih khusus di Kabupaten Nabire belum dapat segera dipecahkan. Akan tetapi, walaupun bidang pendidikan telah ditetapkan sebagai program prioritas, namun dalam pembagian APBD ternyata pendidikan tidak menjadi prioritas. Ketentuan alokasi anggaran pendidikan sebesar 30 persen dari dana otsus (UU Otsus, Perdasus No. 13/2016 dan Pergub No.32/2014) sampai sekarang masih dilanggar oleh eksekutif dan legislatif di Papua. Sebagai gambaran, alokasi anggaran pendidikan di Kabupaten Nabire selama lima tahun terakhir (2011-2015) mengalami pasang surut kurang lebih 30 persen dari dana otsus yang diterima seperti terlihat pada Tabel 1 dibawah ini :

Tabel 1

Perkembangan Penerimaan dan Pembagian dana Otsus Bidang Pendidikan di Kabupaten Nabire Periode 2011-2015

\begin{tabular}{|c|c|c|c|c|}
\hline Tahun & $\begin{array}{c}\text { Penerimaan Dana } \\
\text { Otsus } \\
\text { Rp. }\end{array}$ & $\begin{array}{c}\text { Khusus Bidang } \\
\text { Pendidikan } \\
\text { Rp. }\end{array}$ & $\%$ & $\begin{array}{c}\text { Proporsi } \\
\text { Alokasi } \\
\text { Otsus } \\
\text { Kab/Kota }\end{array}$ \\
\hline 2011 & $55.705 .408 .000,-$ & $12.580 .000 .000,-$ & & $60 \%$ \\
\hline 2012 & $70.955 .679 .300,-$ & $10.800 .000 .000,-$ & 19,08 & $60 \%$ \\
\hline 2013 & $75.347 .769 .000,-$ & $26.273 .790 .000,-$ & 37,02 & $60 \%$ \\
\hline 2014 & $100.989 .297 .000,-$ & $28.869 .120 .175,--$ & 29,07 & $80 \%$ \\
\hline 2015 & $100.989 .297 .000,-$ & $31.246 .789 .100,-$ & 30,94 & $80 \%$ \\
\hline TOTAL & $\mathbf{4 0 3 . 9 8 7 . 4 5 0 . 3 0 0 , -}$ & $109.769 .699 .275,-$ & $\mathbf{2 7 , 1 7}$ & \\
\hline
\end{tabular}

Sumber : Bapeda Kabupaten Nabire 
Alokasi dana Otsus 5 (lima) tahun terakhir dari tahun 2011-2015 sebesar Rp. 403.987.450.300,-, dana tersebut diperuntukan untuk dana pendidikan sebesar Rp. 109.769.699.275 atau sebesar 27,17\%. Dana Otsus yang sangat besar untuk Bidang Pendidikan seperti yang terlihat pada tabel diatas dari tahun ke tahun terjadi peningkatan seharusnya sudah dapat menunjang peningkatan kualitas dan pelayanan pendidikan bagi Orang Asli Papua, baik yang ada di kampung-kampung maupun perkotaan. Namun ternyata dari sejumlah indikator pendidikan ditemukan masih banyak masalah yang belum diselesaikan sesuai yang diharapkan disebabkan oleh pengelolaan dana Otsus yang belum optimal.

Sementara Hal tersebut diatas didukung dengan data BPS Kabupaten Nabire Tahun 2016 dimana Perkembangan Indeks Pembangunan Manusia pada tahun 2010 mencapai 64,49 persen hingga tahun 2015 mencapai 66,49 persen, selama 6 tahun terakhir terjadi perkembangan mencapai 2 persen dari data tersebut dapat dilihat terjadi kemajuan pendidikan tetapi berjalan lambat atau masih jauh dari harapan.

Salah satu penyebab lambatnya peningkatan Indeks Pembangunan Manusia adalah pengelolaan dana Otsus bidang Pendidikan yang mana terdapat fenomena berdasarkan hasil pengamatan penulis bahwa Implementasi pendidikan di era Otsus Kabupaten Nabire telah menunjukan hasil singnifikan namun lebih ditekankan pada pembangunan fisik dan peningkatan mutu pendidikan yang lebih berfokus pada wilayah perkotaan sehingga terjadi kesenjagan pelayanan pendidikan antara daerah perkotaan, terpencil dan kepulauan.

Pembangunan fisik tersebut tidak dilengkapi dengan fasilitas pendukung lainnya seperti fasilitas tambahan buat guru dan murid, kesejahteraan guru, peningkatan mutu dari tim pengajar, honor guru dan penyesuaian kurikulum, sehingga Pemerintah Daerah dianggap belum lokus dan fokus dalam pengalokasian dana Otsus bidang pendidikan.

Hasil pengamatan ini didukung dengan tangapan masyarakat mengenai pendidikan yang dimuat dalam beberapa surat kabar. "Jhon 
Mamboi, (Irawati Aminuddin; Sumber: Harian Indoprogress 2013), Desa Bawei Distrik Teluk Umar, terdapat tujuh siswa tamatan SLTA, belum punya sarjana."

"Menurut Simon Manahara, (Irawati Aminuddin; Sumber: Harian Indoprogress 2013), Anak usia 14-18 tahun duduk bergelombong menguyah pinang tak ada kerjaan karena tidak punya pengetahuan dan pengalaman lain, hanya berkebun dan memiliki orang tua yang tidak mampu membiayainya untuk sekolah, selain itu Desa Napan Yaur memiliki bangunan sekolah yang permanen tetapi kelas melompong karena semua siswa digabung dalam satu kelas disebabkan oleh kurangnya tenaga pegajar, hanya ada satu guru yaitu guru honorer yang gajinya 3 bulan sekali terima di Ibukota Kabupten jadi kalau guru tersebut ke kota maka sekolahpun macet."

"Meskipun sekolah gratis namun sempit pilihan untuk melanjutkan sekolah yang lebih tinggi karena SMP, SMA ada di Kota, mengirim anak kekota berarti mengirim separuh biaya hidup. Pemeritah mengirim uang besar tetapi dia tidak melihat uang diefektifkan memperbaiki kualitas pendidikan di Papua ujar Simon lagi."

"Eddie Pegawai Dinas Pendidikan Nabire ; Kwalitas pendidikan di Nabire angka kelulusan SD 88,88 persen, Kelulusan SMP 72 persen dan Kelulusan SMA merosot menjadi 55,17 persen, sehingga mengindikasikan perlunya kerja keras Pemerintah dan Masyarakat, hal ini mengakibatkan peningkatan penganguran dan kemiskinan, lulusan tersebut tidak menjamin siswa dapat baca tulis." (Inrawati Aminuddin, sumber : Harian Indoprogress 2013).

"Nabire Kota Mati, Bupati Tidur, Kemana Larinya Dana Pendidikan untuk Mahasiswa"? (oleh Oktovianus Pugau, Januari 2013, Melanesia Pos.com). Pernyataan yang sama juga diungkapkan pada Demo Mahasiswa Tahun 2015 yang bunyinya " 5 tahun dana pendidikan hilang, mahasiswa mulai aksi." dengan Topik: "Dana Pendidikan Tinggal Kenangan." Sejak tahun 2011 Hingga tahun 2015 kami tidak mendapatkan dana pendidikan sedangkan sebelumya setiap tahun kami dibantu untuk Mahasiswa Tugas 
Akhir tidak seperti sekarang dan tidak sesuai dengan janji pemimpin yang sekarang. (sumber: Zona Dinamika.com.)

Hal tersebut diatas didukung oleh Pernyataan "Gubernur Papua dalam Sambutannya Pada Seminar Efektivitas Pengunaan dan Pengelolaan Dana Otonomi Khusus Papua dan Papua Barat (Sorong, 27 Agustus 2015), Total Dana Otsus yang diterima Provinsi Papua dalam periode 2002 - 2015 adalah Rp. 42 trilyun lebih, sedang Dana Tambahan Infrastruktur sebesar Rp.10 trilyun lebih untuk periode TA 2006-2015. Jadi total dana selama 14 tahun sebesar Rp. 52 trilyun lebih, belum dapat Meningkatkan Index Pembangunan Manusia setara rata-rata standar Nasional dan belum dapat meningkatkan SDM Orang Asli Papua.

Sebagian besar masyarakat di Papua menghendaki agar Pemerintah aktif mengambil peran dalam meluruskan pengelolaan dana Otonomi Khusus Papua. (Agustinus Salle, 2011) menjelaskan masalah transparansi, partisipasi, regulasi, sanksi, pembagian dana ke Kabupaten/Kota, alokasi untuk urusan prioritas, dan keberpihakan kepada Orang Asli di kampungkampung sangat penting diawasi Pemerintah. Tanpa campur tangan ini, dana Otsus tidak dapat diharapkan untuk mengangkat harkat dan martabat Orang Asli Papua dan dapat dipastikan banyak orang di Papua akan mengatakan "tidak ada kesungguhan Pemerintah membangun Papua".

Semua fakta di atas kemudian menimbulkan tanda tanya dan keraguan masyarakat, yaitu "kemana uang Otsus itu?" Kajian ini diarahkan untuk menjawab pengelolaan keuangan Otsus dalam bidang pendidikan, dengan harapan bahwa hasil kajian nantinya dapat digunakan sebagai informasi dalam pengambilan kebijakan Pemerintah Daerah untuk implementasi Otonomi Khusus yang lebih baik.

Berdasarkan kondisi tersebut, maka tujuan penelitian dapat dijelaskan sebagai berikut : (1) Menganalisis secara mendalam Implementasi Pengelolaan Dana Otonomi Khusus Bidang Pendidikan; (2) Mengidentifikasi Secara Mendalam Permasalahan yang dihadapi dalam Pengeloaan Dana Otonomi Khusus Bidang Pendidikan; (3) Menganalisis secara mendalam 
penyelesaian masalah pengelolaan dana Otonomi Khusus Bidang Pendidikan.

Baridzwan (1998) menjelaskan bahwa Sistem Biasanya melibatkan beberapa orang dalam satu bagian atau lebih, disusun untuk menjamin adanya perlakuan yang seragam terhadap transaksi-transaksi yang terjadi dalam suatu organisasi.

Dalam kaitan iitu, Mamesah, (1995) memberikan definisi Keuangan Daerah adalah semua hak dan kewajiban yang dapat dinilai dengan uang, demikian pula segala sesuatu baik berupa uang maupun barang yang dapat dijadikan kekayaan daerah sepanjang belum dimiliki/dikuasai oleh negara atau daerah yang lebih tinggi, serta pihak lain sesuai dengan ketentuan peraturan yang berlaku.

Sedangkan Permendagri No.13 Tahun 2006 Tentang Pedoman Pengeloaan Keuangan Daerah, Keuangan Daerah adalah semua hak dan kewajiban daerah dalam rangka penyelenggaraan Pemerintahan Daerah yang dapat dinilai dengan uang termasuk di dalamnya segala bentuk kekayaan yang berhubungan dengan hak dan kewajiban daerah tersebut. Pengelolaan Keuangan Daerah adalah keseluruhan kegiatan yang meliputi perencanaan, pelaksanaan, penatausahaan, pelaporan, pertanggung jawaban, dan pengawasan keuangan daerah.

Rhodes (2000) menjelaskan Akuntabilitas berkaitan dengan pelaksanaan merupakan evaluasi (penilaian) mengenai standar pelaksanaan kegiatan, apakah standar yang dibuat sudah tepat dengan situasi dan kondisi yang dihadapi, dan apabila dirasa sudah tepat, manajemen memiliki tanggung jawab untuk mengimplementasikan standar-standar tersebut.

United Nations Development Program (UNDP. 2007) akuntabilitas pelaporan memiliki kerangka hukum, diartikan bahwa adanya jaminan kepastian hukum dan rasa keadilan masyarakat terhadap setiap kebijakan publik yang dibuat dan dilaksanakan. Selanjutnya akuntabilitas pelaporan pada pemerintahan adalah akuntabilitas dengan karakteristik Good Governance, yaitu: (1) partisipasi; (2) transparansi; (3) akuntabilitas; (4) 
efektif dan efisien; (5) mengembangkan kepastian hukum; (6) responsif; (7) concensus oriented; dan (8) equity and inclusiveness.

Berdasarkan uraian pada latar belakang dan pendapat para pakar diatas fokus penelitian diarahkan pada pertanyaan penelitian tentang 1) Pelaksanaan Implementasi pengelolaan Dana Otsus Bidang Pendidikan. 2) Permasalahan yang dihadapi dalam pengelolaaan Dana Otsus Bidang Pendidikan dan, 3) Pemecahan masalah yang dihadapi tersebut.

\section{METODE PENELITIAN}

Pendekatan yang digunakan yaitu pendekatan kualitatatif dengan dukungan data primer yang diperoleh langsung dari informan kunci. Sementara data sekunder melalui buku-buku atau dokumen pendukung seperti (1) Nabire dalam angka; (2) URD/RD Otsis; (3) LAKIP, (4) Hasil Monev kajian Otsus Papua (Bappeda), (5) Perdasus No.13 Tahun 2016, (6) Pergub No. 32 Tahun 2014, (7) RPJMD Tahun 2016, dan (8) Data dari Internet. Proses analisis data yang dilakukan pada penelitian ini mengacu kepada proses analisis data yang disampaikan oleh Miles dan Huberman (1962: 16) yaitu: setelah data dibaca, dipelajari, dan ditelaah, maka selanjutnya data direduksi, disajikan, dan ditarik kesimpulan serta verifikasinya.

\section{PEMBASAHAN}

Implementasi Pengelolaan Dana Otonomi Khusus bidang Pendidikan. Sejak awal implementasi Otsus, kebijakan baru untuk Papua ini sudah menuai kritikan di Papua. Banyak elite dan generasi muda Papua menilai kebijakan Otsus tidak akan membawa kemajuan bagi Papua. Kebijakan Otsus bagi banyak penduduk asli Papua seringkali dinyatakan "gagal".

Beberapa faktor yang sering disebut sebagai penyebab kegagalan antara lain: (1) Pemerintah Indonesia tidak membuka diri untuk berdialog tentang masalah konflik Papua, (2) kegagalan dalam menetapkan regulasi 
implementasi Otsus, (3) masalah HAM, (4) Pemekaran daerah yang memicu arus migrasi masuk, dan (5) Kemiskinan yang kurang tersentuh (Tebay, 2009, dan Demo DAP 12 Agustus 2005).

Selain masalah di atas, beberapa permasalahan dalam tatakelola OTSUS juga disebabkan karena faktor internal Pemda di Papua, seperti (1) Rendahnya kapasitas aparatur dalam mengelola pembangunan, (2) Aparat daerah tidak inovatif tetapi lebih banyak menunggu arahan dari pemerintah atasan, (3) Koordinasi Eksekutif, Legislatif dan Perwakilan Kultural (MRP), dan (4) Koordinasi Pemerintah Pusat dengan Pemerintah Daerah, dan kebijakan pemekaran Provinsi Papua Barat (Mambor, 2008).

Keputusan Gubernur tentang Petunjuk Pengelolaan Dana Penerimaan khusus Dalam Rangka Otonomi Khusus Papua yang dikeluarkan setiap tahun anggaran secara umum mengatur beberapa kebijakan pokok sebagai berikut.

Penerimaan Dana Otsus adalah untuk memperkuat kemampuan keuangan daerah dalam rangka mempercepat pembangunan di Provinsi Papua, dengan tujuan (a) mendukung pelaksanaan Otonomi Khusus bagi Provinsi Papua, (b) meningkatkan taraf hidup dan kesejahteraan masyarakat, (c) meningkatkan kualitas sumber daya manusia, (d) mengurangi kesenjangan pembangunan antar bidang, antar wilayah serta antar desa dan kota, dan (e) menjaga konsistensi dan kesinambungan pembangunan di Provinsi Papua.

Sasaran penggunaan dana Otsus adalah (a) meningkatnya pemerataan dan mutu pelayanan di bidang pendidikan, (b) meningkatnya pemerataan dan mutu pelayanan di bidang kesehatan, (c) berkembangnya ekonomi rakyat, (d) meningkatnya pemerataan dan mutu pelayanan di bidang perhubungan, (e) meningkatnya kualitas hidup masyarakat, (f) penciptaan dan perluasan lapangan kerja di daerah, (g) meningkatnya kesejahteraan masyarakat.

Program prioritas meliputi: pendidikan 30 persen, kesehatan 15 persen, pemberdayaan ekonomi rakyat, pembangunan pengembangan infrastruktur, 
dan pemberdayaan distrik dan masyarakat kampung. Program-program penunjang, meliputi: (a) pembinaan umat beragama, hukum dan hak asasi manusia (HAM), tenaga kerja, aparatur pemerintah dan kelembagaan, pembinaan pemuda, pembinaan prestasi olahraga, pemberdayaan perempuan, kependudukan dan pemukiman, pariwisata, kebudayaan, lingkungan hidup, stabilitas perbatasan, ketentraman dan ketertiban, (b) penyediaan prasarana dan sarana fisik pemerintahan, khususnya bagi kabupaten pemekaran, dan (c) penyusunan data dan informasi untuk perencanaan pembangunan, dan (d) pengendalian, pengawasan, dan evaluasi pelaksanaan rencana pembangunan.

Perencanaan pembangunan dan penganggaran daerah di Provinsi Papua menggunakan mekanisme yang ditetapkan UU/25/2004 tentang Sistem Perencanaan Pembangunan Nasional Permendagri 57/2007 tentang Pedoman Pengelolaan Keuangan Daerah. Pelaksanaan program/kegiatan berpedoman pada ketentuan dan peraturan yang berlaku, termasuk Keputusan Gubernur tentang Petunjuk Pengelolaan Dana Penerimaan Khusus dalam Rangka Otonomi Khusus Papua, dan disesuaikan dengan kebutuhan dan kondisi daerah.

Pengendalian, pengawasan, dan evaluasi. Pengendalian pelaksanaan program/kegiatan dilakukan untuk mendapatkan data dan informasi terkini tentang perkembangan pelaksanaan pekerjaan, baik fisik maupun keuangan. Pengawasan dilakukan untuk meningkatkan daya guna dan hasil guna program/kegiatan yang dilaksanakan saat selesainya pekerjaan. Evaluasi dilaksanakan untuk menilai sampai sejauh mana program atau kegiatan dapat mencapai tujuannya dan upaya apa yang perlu dilakukan untuk memperbaiki bila ada masalah pencapaian tujuan.

Pengalokasian Dana Otonomi Khusus bidang Pendidikan. Penetapan jumlah Dana Otsus yang akan diterima Papua dilakukan oleh Pemerintah Pusat setelah pengesahan APBN, Pemerintah Pusat menganggarkan Dana Alokasi Umum sebagai dasar perhitungan Dana Otsus Papua. Jumlah Dana Otsus untuk Papua dihitung 2 persen dari DAU 
Nasional. Berdasarkan perhitungan Kementerian Keuangan mengeluarkan Peraturan Menteri Keuangan tentang Alokasi Dana Otonomi Khusus, Peraturan Menteri Keuangan Nomor 126 tahun 2010 telah mengubah dari empat tahap menjadi tiga tahap sebagai berikut. Tahap I bulan Maret 30 persen, Tahap II bulan Juli 45 persen dan Tahap III bulan Oktober 25 persen.

Selanjutnya petunjuk pelaksanaan dana Otsus khususnya bidang pendidikan diatur dalam Peraturan Gubernur Papua No. 32 Tahun 2014 tentang Petunjuk Pelaksanaan dan Pengunaan Dana Otonomi Khusus Bidang Pendidikan bagi Kabupaten/Kota di Provinsi Papua. Rincian Pengalokasian Dana Otsus tersebut diatur dalam Pasal 12 Pergub. No.32 Tahun 2014, dimana terdiri dari beberapa program Prioritas : -) Paud Non Formal dan Formal (5\%), -) Wajar Diknas 9 Tahun - SD (32\%), -) Wajar Diknas 9 Tahun - SMP(25\%), -) Sekolah Menengah Atas (15\%),-) Sekolah Menengah Kejuruan (10\%), -) Pendidikan Non Formal dan Informal (3\%), -) Pendidikan Tinggi dan Pendidikan lain yang Relevan 10 persen.

Pengalokasian dana Otsus yang diterima di kabupaten Nabire selama kurun waktu lima tahun dari tahun 2011 hingga 2015 dapat didilihat pada tabel 1. dibawah ini :

Tabel. 1.

Perkembangan Penerimaan dan Pembagian dana Otsus Bidang Pendidikan di Kabupaten Nabire Periode 2011-2015

\begin{tabular}{|c|c|c|c|c|c|}
\hline Tahun & $\begin{array}{c}\text { Penerimaan Dana } \\
\text { Otsus Provinsi } \\
\text { Papua } \\
\text { Rp. }\end{array}$ & $\begin{array}{c}\text { Penerimaan Dana } \\
\text { Otsus Kab. Nabire } \\
\text { Rp. }\end{array}$ & $\begin{array}{c}\text { Khusus Bidang } \\
\text { Pendidikan } \\
\text { Rp. }\end{array}$ & $\%$ & $\begin{array}{c}\text { Proporsi } \\
\text { Alokasi } \\
\text { Otsus } \\
\text { Kab/Kota }\end{array}$ \\
\hline 2011 & $3.157 .500 .000 .000,-$ & $55.705 .408 .000,-$ & $12.580 .000 .000,--$ & & $60 \%$ \\
\hline 2012 & $3.833 .402 .135 .000,-$ & $70.955 .679 .300,-$ & $10.800 .000 .000,-$ & 19,08 & $60 \%$ \\
\hline 2013 & $4.355 .950 .048 .000,-$ & $75.347 .769 .000,--$ & $26.273 .790 .000,--$ & 37,02 & $60 \%$ \\
\hline 2014 & $4.777 .070 .560 .000,-$ & $100.989 .297 .000,-$ & $28.869 .120 .175,--$ & 29,07 & $80 \%$ \\
\hline 2015 & $4.940 .429 .880 .000,-$ & $100.989 .297 .000,-$ & $31.246 .789 .100,-$ & 30,94 & $80 \%$ \\
\hline
\end{tabular}

Sumber : Bapeda Kabupaten Nabire

Dari tabel diatas dapat disimpulkan bahwa setiap tahunnya terjadi kenaikan dana otsus khususnya bidang pendidikan tetapi dalam pengelolaannya tidak sesuai dengan kebutuhan daerah karena dalam pengelolaannya sudah diatur oleh Pemerintah Provinsi dan Pemerintah 
Pusat. Hal itu didukung dengan hasil wawancara Peneliti $(\mathrm{P})$ dengan Sekertaris Daerah (SD), berikut hasil petikan wawancaranya:

"Pengelolaan Dana Otsus Bidang Pendidikan Di Kabupaten Nabire, cukup baik dimana Undang-Undang otsus porsi Porsi $30 \%$ untuk pendidikan sangat menolong untuk pengembangan bidang pendidikan di Kab. Nabire karena sumber dana lain terbatas sehingga dengan dana otsus menurut $\mathrm{Pa}$ Lukas $80 \%$ untuk Kab/Kota dan $20 \%$ untuk Provinsi. 30\% kami alokasikan maksimal untuk bidang pendidikan, baik yang dikelolah di Dinas Pendidikan, Sekolah-sekolah tetapi juga untuk bantuan Mahasiswa dan anak-anak SMU/SMK dalam bidang afirmasi dan juga dinasdinas lain yang berkaitan dengan peningkatan pelayanan Pendidikan di Kabupaten Nabire."

Perencanaan/Penganggaran Dana Otonomi Khusus bidang Pendidikan. Kebijakan Dana OTSUS sudah ditetapkan dalam kerangka mensejahterahkan masyarakat Khususnya OAP. Sejalan dengan pernyataan tersebut, Perdasus 13 Tahun 2016 telah memperuntukkan Dana OTSUS untuk dikelola oleh Kabupaten di Provinsi Papua dengan pedoman perencanaan dan penganggaran khususnya bidang kesehatan bahwa 30 persen alokasi dana OTSUS ditujukan untuk PAUD, Pendidikan Dasar 9 Tahun, Pendidikan Menengah, dan Pendidikan Tinggi.

Secara konseptual dan mekanisme proses penyusunan perencanaan dan penganggaran telah sesuai dengan Perdasus 13 Tahun 2016 berdasarkan opini yang disampaikan oleh responden yang diwawancarai. Dalam proses perencanaan dan penganggaran pada tingkat OPD, terdapat beberapa hal teknis yang perlu dipertimbangkan oleh Pengelola Program dan Pimpinan OPD pada lingkungan Pemerintah Daerah. Secara konsistensi strata dokumen Usulan Rencana Defenitif (URD) yang disusun oleh setiap OPD perlu konsisiten dengan beberapa Dokumen Perencanaan lainnya antara lain: (1) RENSTRA OPD, (2) RENJA OPD.

Isu pada umumnya bahwa banykanya OPD yang belum secara lengkap memiliki dokumen perencanaan yang berkualitas pada tingkat OPD, secara struktur organisasi bahwa fungsi ini menjadi salah satu pengawasan 
dari BAPPEDA Kabupaten Nabire. Dengan minimnya kualitas dokumen perencanaan maka dapat diasumsikan bahwa URD yang disusun dan direncanakan belum secara maksimal bersinergi dengan dokumen perencanaan lainnya. Selain itu juga proses MUSRENBANG yang dilakukan belum maksimal dipetakan untuk kebutuhan Roh OTSUS dalam kerangka peningkatan ak ses dan mutu pembangunan pendidikan di Kabupaten Nabire.

Selain banyaknya tantangan pada tahapan perencanaan dana OTSUS, pada tahapan penganggaran, kegiatan yang bersumber dari OTSUS menggunakan tahapan penganggaran pada umumnya yakni RKA dan DPA OPD, sering terjadi inkonsisten, hal ini juga dibenarkan oleh beberapa narasumber, terdapat beberapa opini yang dapat menjustifikasi kondisi ini ialah dimana URD OTSUS hanya digunakan sebagai simbol administrasi suatu perencanaan.

Pelaksanaan Dana Otonomi Khusus Bidang Pendidikan. Sepanjang tahun 2011-2015 Pembangunan Pendidikan melalui Dana OTSUS telah menghabiskan anggaran sebesar Rp.109 Milliar, pelaksanaan kegiatan dana OTSUS tentunya harus merujuk pada RD-OTSUS yang telah disetujui oleh Gubernur Provinsi Papua. Berbagai cerita sukses yang telah diraih dalam rangka meningkatkan akses, mutu, dan tatakelola pendidikan khususnya bagi Orang Asli Papua.

Pada prinsipnya pelaksanaan dana OTSUS dikucurkan masih dominan untuk menjawab akses pelayanan pendidikan bagi Orang Asli Papua. Berdasarkan hasil wawancara mendalam dengan stakeholder kunci, beberapa kegiatan prioritas antara lain: Membayar tenaga guru honor, pembangunan gedung sekolah, biaya operasional sekolah, Beasiswa, Peralatan Belajar Mengajar. Berdasarkan Perdasus 13 Tahun 2016 peruntukan dana OTSUS Bidang Pendidikan sebesar 30 persen dari Total Penerimaan Dana OTSUS Daerah, diarahkan untuk membiayai kegiatan bagi PAUD, Pendidikan Dasar 9 Tahun, Pendidikan Menengah, dan Pendidikan Tinggi. 
Berdasarkan informasi yang diperoleh dari stakeholder, nuansanya bahwa kegiata Dana OTSUS cenderung memiliki sifat yang tidak langsung mengarah kepada peserta didik Orang Asli Papua, artinya bahwa dana OTSUS masih dialokasikan untuk membayar gaji/honor guru, membiayai operasional atau keperluan administrasi perkantoran.

Sepatutnya pembiayaan untuk kegiatan-kegiatan ini bersumber dari dana lainnya, sehingga dana OTSUS diarahkan kepada kegiatan yang memiliki sifat langsung kepada peserta didik Orang Asli Papua seperti, pembebasan biaya sekolah, beasisswa, belanja seragam sekolah, peralatan sekolah, peralatan belajar mengajar, dsb. Selain itu juga, pengendalian pelaksanaan kegiatan perlu menjadi perhatian Dinas Pendidikan maupun BAPPEDA Kabupaten Nabire, untuk memastikan bahwa pihak ketiga melaksanakan kegiatan sesuai dengan kesepakatan/kontrak kerja.

Pengendalian kegiatan ini seringkali terabaikan dalam proses pelaksanaan kegiatan, hal ini sangat penting dalam memastikan bahwa perkembangan kegiatan mengarah kepada suatu hal yang diharapkan pada saat proses penyusunan perencanaan. Fungsi pengendalian program kegiatan selain internal SKPD pengelola Dana OTSUS, peran BAPPEDA, sebagai lintas SKPD perlu menjamin bahwa keseluruhan pelaksanaan kegiatan Dana OTSUS berjalan dengan baik, untuk itu BAPPEDA perlu secara periodik melakukan pengendalian dengan melalui pertemuan koordinasi antar SKPD pengelola Dana OTSUS. Beberapa hal yang bersifat sederhana dan menjadi tugas utama, baik itu SKPD pengelola Dana OTSUS maupun BAPPEDA yang memiliki fungsi sebagai pengendali pembangunan daerah sering belum berjalan optimal.

Pelaporan Dana Otonomi Khusus Bidang Pendidikan. Secara umum, berdasarkan informasi yang diperoleh menunjukkan bahwa seluruh entitas sudah menyusun dan mempertanggungjawabkan keuangan OTSUS melalui bentuk akuntabilitas "Laporan Keuangan". Namun sejauh ini, masih terdapat beberapa entitas yang belum mampu untuk menyusun sesuai dengan waktu yang ditentukan, hal ini berdampak kepada waktu penyampain 
laporan realisasi OTSUS baik secara triwulan, semester, maupun tahunan kepada pihak Provinsi Papua.

Makna pelaporan dari sudut pandang berbeda yakni dari segi transparansi kinerja program/kegiatan maupuan keuangan dan OTSUS kepada publik belum menjadi prioritas, hal ini ditunjukkan dengan opini publik yang banyak mengatakan bahwa Dana OTSUS ini kami tidak tahu dibuat apa. Hal ini didukung oleh beberapa pernyataan yang disampaikan oleh para pakar dalam Salle bahwa Pelaporan publik (Public Reporting) terkait dengan aktivitas organisasi dalam menyediakan informasi bagi masyarakat. Lee (2004, p.7) Dalam Agus Salle menjelaskan public reporting sebagai:

"the management activity intended to convey systematically
and regularly information about government operations, in
order to promote an informed citizenry in a democracy and
accountability to public opinion. It consists of direct and
indirect reporting of the government's record of
accomplishments and stewardship of the taxpayers' money.
Public reporting is presented in many different
communication formats, but always uses vocabulary that is
understandable and meaningful to lay citizens."

Ide penting dalam pendapat Lee di atas yaitu, informasi aktivitas pemerintahan yang secara berkala disampaikan pemerintah kepada warga. Informasi dapat disampaikan secara langsung, dalam bahasa dan format yang disusun pemerintah, atau secara tidak langsung, pemerintah menyampaikan pokok pikiran kemudian diterjemahkan dan dituliskan oleh media. Penyampaian informasi secara langsung atau tidak langsung dilakukan pemerintah melalui media cetak atau elektronik, termasuk media internet. Cara apapun yang dipakai, disyaratkan agar menggunakan bahasa dan perbendaharaan kata yang mudah dipahami masyarakat.

Dua hal ini menjadi salah satu temuan penting yang dikembangkan dalam analisis keuangan OTSUS di Bidang Pendidikan, dimana memaknai pelaporan bukan hanya dari sudut pandang seni pencatatan secara akuntansi namun juga dari sudut pandang akuntabilitas dan transparansi keuangan OTSUS Pendidikan kepada penerima manfaat secara langsung, 
sehingga tingkat kepercayaan masyarakat kepada Pemerintah Daerah dapat secara bertahap meningkat.

Monitoring dan Evaluasi Dana Otonomi Khusus Bidang Pendidikan. PERDASUS 13 Tahun 2016 Pasal 10 Ayat 2 huruf $d$ menyatakan secara jelas bahwa selain urusan strategis lainnya MONEV OTSUS perlu mendapatkan perhatian serius di bidang pendidikan. Situasi saat ini, MONEV OTSUS masih bersamaan dengan MONEV APBD pada umumnya, diketahui bersama bahwa banyaknya jumlah kegiatan dan keterbatasan SDM mampu mendorong kualitas dari MONEV OTSUS.

Dalam ruang lingkup Kabupaten Nabire, BAPPEDA menjadi Leading dalam pelaksanaan seluruh urusan pembangunan, namun secara entitas pengelola dana OTSUS, perlu memiliki mekanisme yang ditetapkan dalam sebuah peraturan daerah untuk ditaati oleh seluruh entitas yang secara langsung mendapatkan dan mengelola keuangan OTSUS.

Namun sejak diberlakukakannya Perdasus 13 Tahun 2016, belum banyak potret MONEV yang dilaksanakan secara kolaborasi yang melibatkan Perguruan Tinggi dan Pihak Akademisi. Selain itu juga permasalahan yang terjadi ialah proses MONEV hanya difokuskan kepada MONJA (Monitoring Meja) ataupun hanya sebatas Realisasi Fisik dan Keuangan, namun evaluasi Dampak OTSUS Bidang Pendidikan masih sangat terabaikan dalam skema pengelolaan OTSUS Bidang pendidikan.

Pada tahun 2016 melalui BAPPEDA Provinsi Papua, serta melibatkan beberapa unsur perguruan tinggi dan DPRD melaksanakan MONEV OTSUS. Banyak kondisi yang menjadi dasar bagi perbaikan-perbaikan kedepan, salah satu hal yang perlu di tekankan bahwa sejatinya ialah UU OTSUS 21 Tahun 2001 tidak dapat direduksi menjadi UU teknis.

Pengawasan/Pemeriksaan Internal Dana Otonomi Khusus Bidang Pendidikan. Pada pasal 26 MRP, DPRP/DPRD, dan aparatur pengawasan internal kabupaten melakukan pengawasan terhadap pelaksanaan peraturan daerah khusus ini, dan Perencanaan, pelaksanaan, pertanggungjawaban dan pelaporan penggunaan dana otonomi khusus wajib dipublikasikan oleh 
Pemerintah Daerah kepada masyarakat. Pada prinsipnya pengawasan dan pemeriksaaan internal dari inspektorat berjalan dengan baik.

Secara konseptual, menurut pengawasan manulang (2004:173) pengawasan adalah mengusahakan agar apa yang direncanakan menjadi kenyataan. Untuk dapat benar-benar merealisasikan tujuan utama tersebut, maka pengawasan pada taraf pertama bertujuan agar pelaksanaan pekerjaan sesuai dengan instruksi yang telah dikeluarkan dan untuk mengetahui kelemahan serta kesulitan yang dihadapi dalam pelaksanaan rencana berdasarkan penemuan-penemuan tersebut dapat diambil tindakan untuk memperbaikinya baik pada waktu itu maupun waktu yang akan datang.

Berlandaskan pada kosnep tersebut, pengawasan dari Pemerintah Provinsi dalam hal ini Dinas Pendidikan Provinsi, DPRD, Masyarakat khususnya komite sekolah dan pemerhati pendidikan menjadi bagian yang sangat penting sebagai strategi pengawasan penggunaan Dana OTSUS Bidang pendidikan.

\section{Permasalahan Yang Dihadapi Dalam Pengelolan Dana Otonomi} Khusus Bidang Pendidikan. Dengan berbagai kinerja keuangan OTSUS di Bidang pendidikan maupun Kinerja Capaian Program yang cukup mengemberikan. Namun dalam hal pengelolaan Dana Otonomi Khusus Bidang pendidikan, masih dijumpai berbagai persoalan yang perlu mendapat perhatian bersama khususnya dalam pengelolaan Dana OTSUS Bidang Pendidikan. Dana Pembangunan yang bersumber dari OTSUS sebaiknya tidak dipatok dalam persentase, hal ini akan menyulitkan daerah untuk melakukan perencanaan sesuai dengan tingkat permasalahan pendidikan didaerah.

Selain itu juga persolan perencanan Program Kegiatan OTSUS Pendidikan masih belum maksimal dalam penggunaan Perdasus 13 Tahun 2016, sepatutnya dalam penyusunan Program Kegiatan OPD Pendidikan perlu melihat bagaimana arah penggunaan Dana OTSUS Bidang Pendidikan yang telah ditetapkan, sehingga kepatuhan terhadap PERDASUS perlu menajdi perhatian kedepan. 
Selain itu, pemahaman masyarakat yang rendah terkait mekanisme Dana OTSUS menjadi tantangan kedepan, dimana dengan melibatkan masyarakat dalam pengawasan pelaksanaan Dana OTSUS, sebaiknya masyarakat diberikan pemahaman dan pengertian yang intens terkait mekanisme pengelolaan Dana OTSUS Bidang Pendidikan, Permasalahan lain yang berkaitan ialah Transparansi Pengelolaan Dana OTSUS Bidang pendidikan, transparansi antara OPD Pendidikan dengan Unit Layanan diseluruh jenjang pendidikan, maupun kepada masyarakat.

Transparansi sangat penting, dengan terciptanya transparansi yang handal akan berdampak pada tingginya partisipasi masyarakar maupuan unit layanan dalam pembangunan pendidikan khususnya peningkatan SDM Orang Asli Papua.

Ironis sekali hubungan koordinasi dan komunikasi antara Provinsi dengan daerah, misalnya Kabupaten Nabire terdapat persoalan yang cukup mendasar dalam pelaksanaan Dana Otonomi Khusus. Regulasi merupakan input dalam pengelolaan keuangan daerah, namun hingga saat ini terdapat opini bahwa regulasi PERGUB mengenai seluruh aturan mengenai OTSUS yang dikeluarkan oleh Provinsi belum maksimal disosialisasikan kepada Kabupaten Nabire.

Hal ini merupakan suatu persoalan komunikasi antar level pemerintah daerah yang belum berjalan maksimal dalam mengelola dana OTSUS, selain itu Dana OTSUS sepertinya hanya untuk pemerataan pendapatan di seluruh OPD di Kabupaten Nabire.

Walaupun menurut OPD terdapat keberhasilan dalam penyelenggaraan Pendiikan di Kabupaten Nabire terkait OTSUS, bahwa Dana OTSUS ini telah memberikan dampak positif melalui instrumen perencanaan program kegiatan setiap tahunnya, Kondisi ini memberikan informasi bahwa, terdapat perbedaan informasi yang diperoleh mengenai dampak terhadap OTSUS tersebut, menurut pemerintah daerah dana yang dituangkan dalam program kegiatan telah banyak disalurkan kepada unit layanan dalam kerangka layanan publik dalam bidang pendidikan bagi Orang 
Asli Papua, namun dari segi masyarakat belum adanya manfaatyang signifikan bagi masyarakat, hal senada seperti diungkapkan diatas bahwa masih banyak anak-anak papua asli yang belum sekolah, padahal roh 30 persen dana OTSUS tersebut untuk meningkatkan partisipasi usia sekolah. Tentunya ini menjadi persoalan dalam membangun kepercayaan masyarakat terhadap pemerintah daerah dalam mengelola Dana OTSUS.

\section{Mengatasi Masalah Pengelolaan Dana Otonomi Khusus Bidang}

Pendidikan. Pemerintah Daerah telah mengupayakan pembangunan Pendidikan dengan semaksimalkan mungkin, memang diketahui masih banyak kekurangan yang perlu di perbaiki, baik dari segi perencanaan, penganggaran, pelaksanaan, pelaporan, evaluasi memiliki tantangan yang tidak berbeda jauh dengan kabupaten lainnya. perlu investasi yang cukup besar dengan strategi fokus dan konsisten kedepannya.

Persoalan pengalokasian Dana OTSUS sesuai peruntukan pada Perdasus 13 Tahun 2016, perlu dipertimbangkan kedepan untuk memaksimalkan pengentasan persoalan yang bersifat genting dalam setiap tahun perencanaan. Kebijakan proporsi dalam arah kebijakan pendidikan perlu dibijaki kembali, sebab pola tersebut kurang efektif. sebab kebutuhan daerah sangatlah berbeda.

Disamping itu keberpihakan perencanaan dan penganggaran terhadap OAP perlu di tingkatkan, hal ini menjadi bagian tanggungjawab kabupaten/kota untuk berperan penting dalam meningkatkan kualitas perencanaan dan penggaran yang berpihak apda Orang Asli Papua.

Transparansi, partisipasi, dan akuntabilitas perlu mendapatkan perhatian serius dari OPD, dalam mengelola Dana OTSUS ini. Dari segi transparansi bahwa, antara pemerintah daerah perlu ada transparansi pengelolaan dana OTSUS, antara pemerintah daerah dan masyarakat perlu disosialisasikan dengan cara setiap kegiatan perlu disampaikan bahwa ini dari Dana OTSUS. Sehingga masyarakat tahu, bahwa dana OTSUS sudah menyentuh kehidupan mereka. 
Selain itu dari segi partisipasi bahwa dari tahapan perencanaan, pelaksanaan, dan evaluasi setiap unit pendidikan dan lebih khusus masyarakat perlu dilibatkan hal ini seharusnya mutlak harus ditindak lanjuti sehingga kebersamaan dalam kepemilikan Dana OTSUS ini menjadi lebih baik, selanjutnya dari segi akuntabilitas, pemerintah daerah memiliki kewajiban untuk mampu mempertanggungjawabkan Dana OTSUS kepada Pemerintah Daerah, Pemerintah provinsi, dan lebih penting kepada masyarakat asli papua di Kabupaten Nabire setiap tahunnya. Akuntabilitas dapat terwujud melalui bagaimana kualitas perencanaan dan penganggaran, kualitas pelaporan, kualitas hasil yang diperoleh.

\section{KESIMPULAN}

Secara umum Pengelolaan Dana Otonomi Khusus Papua di Kabupaten Nabire telah merujuk kepada peraturan daerah yang mengatur pembagian dan pengelolaan dana Otonomi khusus, namun ditemukan masalah pada unit pelaksana teknis, yaitu kurangnya singkronisasi dalam tahap perencanaan program dan kegiatan, rendahnya koordinasi interen bagian, bidang dan kegiatan dalam OPD, dan berulangnya keterlambatan penyampaian laporan penggunaan penggunaan dana.

\section{DAFTAR PUSTAKA}

Azmi dan Aspirasi Muttaqin (2016). Otonomi Khusus Papua Sebuah Upaya Merespon Konflik Kemerdekaan Papua.

BPKAD. 2015. Seminar efektifitas Pengunaan dan Pengelolaan Dana Otonomi Khusus Papua dan Papua Barat. Sorong

Badan Pusat Statistik. 2016. Nabire Dalam Angka . BPS, Kabupaten Nabire.

Bappeda Provinsi Papua. Rencana Definitif Pengunaan Dana Otonomi Khusus Provinsi Papua Tahun Anggara 2011 s.d 2015 Kabupaten Nabire. Jayapura.

Jhon Agustinus (2014). Analogi Manajemen Keuangan Model Affirmative Action dalam perspektif Otonomi Khusus. (Model Pengeloaan Dana Otsus di Papua). 
Miles dan Huberman. 1962. Analisis Data Kualitatif: Buku Sumber Tenaga Metode-Metode Baru. UI Press. Jakarta.

Moleong. 2007. Metodologi Penelitian Kualitatif. PT. Remaja Rosdakarya Offset. Bandung.

Melanesia Pos.Com. 08 Januari 2013. Nabire Kota Mati, Bupati Tidur, Kemana Larimya Dana Pendidikan Untuk Mahasiswa. Oktovianus pugau. Jayapura.

Peraturan Daerah N0. 05.2006. Pembangunan Pendidikan di Provinsi Papua

Peraturan Daerah Khusus No. 25. 2013. Pembagian Penerimaan dan pengelolaan dana Otonomi Khusus (OTSUS)

Peraturan Gubernur No. 32. 2014. Pelaksanaan Dana Otonomi Khusus (OTSUS) Bidang Pendidikan.

Pramadyanti. 2015. Analisis Pengaruh Dana Otonomi Khusus, Pendapatan Daerah, Belanja Modalterhadap tingkat kesejahteraan di Provinsi Aceh, Papua dan Papua Barat.

Rhodes. 2000. Demon In My View, Delaccorte Press. New York

Rivai dan Basri. 2005. Performance Appraisal: Sistem Yang tepat Untuk Menilai Kinerja Karyawan Dan Meningkatkan Daya Saing Perusahaan. PT. Raja Grafindo Persada. Jakarta.

Salle. Agustinus, 2011. Akuntabilitas Keuangan (Studi Pengelolaan Dana Otonomi Khusus Berdasarkan Undang-Undang Nomor 21 Tahun 2001 tentang Otonomi Khusus Bagi Provinsi Papua). Malang.

Republik Indoensia. Undang-Undang Nomor 21. 2001. Tentang Otonomi Khusus (OTSUS) Bagi Provinsi Papua

-------------.Undang-Undang Nomor 20. 2003. Tentang Sistem Pendidikan Nasional

-Undang-Undang Nomor 25. 2004. Tentang Sistem perencanaan pembangunan Nasional.

Zona Dinamika. Com. 2015. Demo Mahsiswa: Dana Pendidikan tinggal Kenangan. Jayapura. 